\title{
China's Urban and Rural Old Age Security System: Challenges and Options
}

\author{
Wang Dewen \\ Institute of Population and Labor Economics, CASS
}

\begin{abstract}
This paper introduces the development and situation of urban and rural old age security system in China, and discusses the challenges and options in the process of constructing a sustained old age security system. China's pension system now has a high coverage rate for urban workers, but a low coverage rate for rural farmers. Funding gap and empty individual accounts have imposed a heavy burden on the sustainability of urban pension system. The more severe age wave and lower income in rural area pose challenges to the vulnerable rural household support system. The separation of old age security system between rural and urban areas also puts great pressure on the urbanization of landless farmers. Therefore, it is urgent for China to speed up the reform of its old age security system to provide an institutional support for its smooth economic and social transition.
\end{abstract}

Key Words: Pension System Reform, Pay-As-You-Go (PAYG), Fully Individual Contribution Accounts System, Sustainability

In the course of economic transition, China adopted an urban-priority reform path in establishing its old age security system, which conforms to the international development experiences. China's rapid aging at a low-income level, however, is unprecedented in any developed or developing countries. The urban-priority reform ensures a comparatively high coverage in urban area, while imposes a heavy burden of old age support on rural households. Despite the challenges posed by population aging and urbanization, the current old age security system will not definitely go into bankruptcy. If the issues of incentives and availability of pension financing can be solved through sound institutional design, it is possible for China to 
establish a universal basic old age security system at its low-income level to achieve the goal of caring for the growing number of elders.

This paper has five parts: part one introduces the development and situation of urban old age security system reform; part two introduces the development and situation of rural old age security system reform; part three discusses the vulnerability of current urban old age security system; part four analyzes the strategic implications of rural old age security system; part five investigates the role of social security in the alleviation of elderly poverty; the final part examines future challenges and puts forward options to build up a sustained old age security system.

\section{Urban Old Age Security System Reform}

In the planned economy, enterprises or work units were obligated to deliver old age security to urban workers. At that time, the state took a unified management approach to enterprise finance, planning for revenue and expenditures, profits and losses. Enterprises were responsible for both the delivery and administration of basic pensions to their own retirees according to the years of employment and the wage received prior to retirement. The state utilized the form of Pay-As-You-Go system to finance pensions and provided a cradle-to-grave service for urban workers through enterprise-based security system, which intrinsically met the requirement of the planned economy.

The market-oriented reform since late 1970s dismantled the basis for the existence of traditional old age security system. The introduction of enterprise responsibility system and abolishment of lifetime employment system at state-owned enterprises in mid-1980s not only changed the financial relationship between enterprises and the state, but also changed the relationship between enterprises and employees. After the implementation of profit sharing and paying income tax instead of turning profit over to the state, enterprises must partially take the responsibility of accumulating and paying pensions. The Decision on the Reform of Enterprise Pension System promulgated in 1991 specified an overall framework for the establishment of an old age security system. It called for a multi-pillared system combining a social basic pillar with supplemental enterprise-sponsored pensions and individual savings for old age. In this system, pension financing is shared by the government, enterprises and individuals. 
After setting up the framework for old age security system, the reform after mid-1990s mainly focused on the construction of social basic pillar, the enlargement of pension pools and the expansion of insurance coverage. In 1993, the Third Plenary Session of the $14^{\text {th }}$ Communist Party Central Committee promulgated a Decision on Issues of Establishing a Socialist Market Economy System, laying down the principle of establishing the basic old age insurance system through the combination of pooled funds and individual accounts.

In 1997, the State Council promulgated a Decision on Establishing a Uniform Basic Old Age Insurance System for Enterprise Employees, detailing the establishment of an old age security system by implementing a social-pool-plus-individual-accounts scheme. Individual pension accounts were set up at 11 percent of the employee's wage, in which individual contribution increased gradually from 4 percent to 8 percent and the remaining part coming from the enterprises. The ratio of enterprise contribution, set by the provincial government, normally should not exceed 20 percent of the total payroll of the enterprise. This financing strategy is, in essence, a combination of the traditional pay-as-you-go benefits and fully individual contributory system and can be best characterized as a partially individual contributory system.

In August 1998, the State Council promulgated Notification of Issues on Implementing a Provincial Pension Pooling Scheme of Uniform Basic Old Age Insurance System for Enterprise Employees and Switching Sectoral Pension Pooling to Local Management, specifying such measures like consolidating the basic old age insurance systems for enterprise employees across the nation, lifting the pooling of pension funds from city level to province level, shifting from partially to fully subsidizing pension funds, delivering basic pensions by social service institutions.

The Interim Measures for Collecting Social Basic Insurance Premium, promulgated by the State Council in January 1999, expanded the pooling of social basic pension funds to include state-owned enterprises, urban collective enterprises, foreign-invested enterprises, urban private enterprise and other types of urban enterprises and institutions managed as enterprises. In addition, local governments can decide whether to include the self-employed in the pooling of social basic pension funds based on their conditions.

The Pilot Program on Improving the Urban Social Security System, promulgated by the State Council in 2000, decided to carry out pilot projects in Liaoning Province and selected cities in 
some other provinces, autonomous regions and municipalities directly under the Central Government starting form 2001. Compared with the 1997's Decision on Establishing a Uniform Basic Old Age Insurance System for Enterprise Employees, this program intends to minimize the transition cost and ensure that individual pension accounts are genuinely funded through a series of measures, including making individual pension accounts solely contributed by individuals, separating the management of social pooling accounts and individual accounts, adjusting and improving the delivery of basic pensions and encouraging enterprise-sponsored annuities.

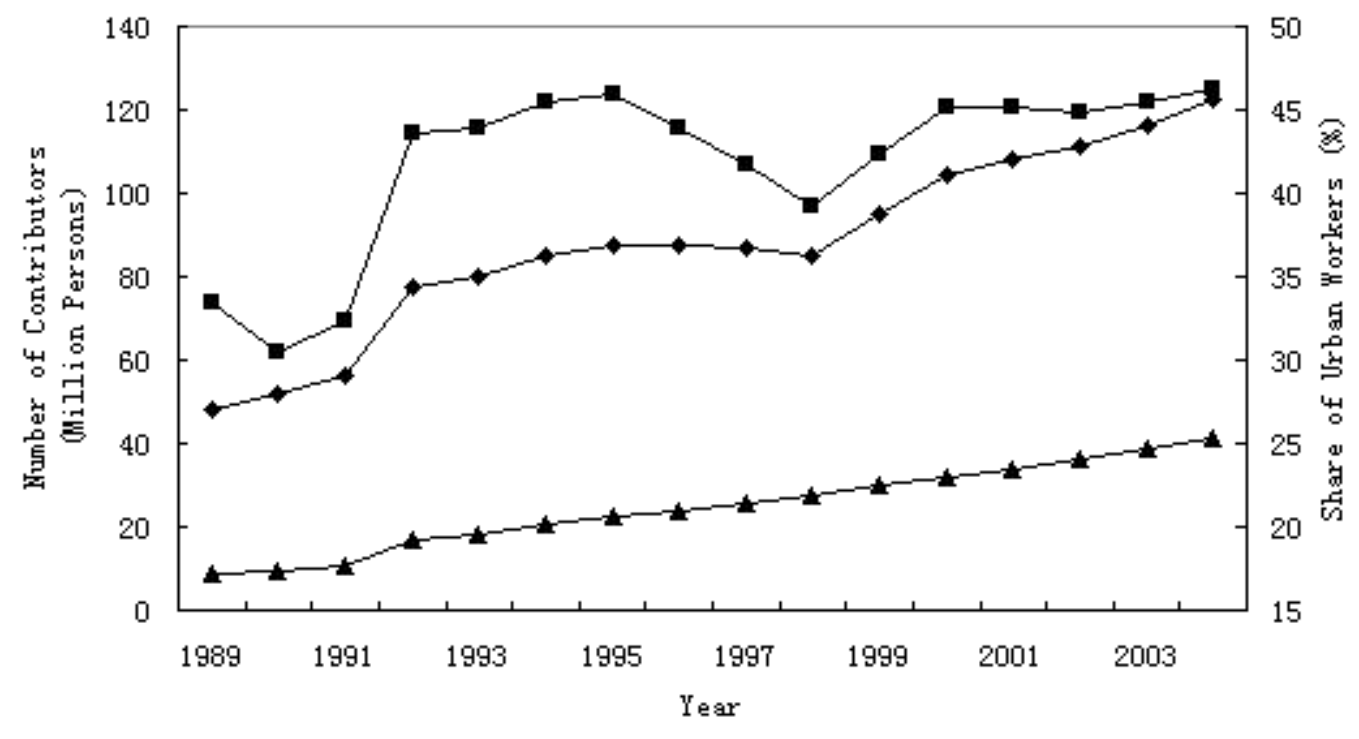

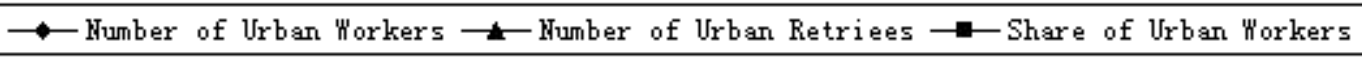

Figure 1. Coverage of Urban Basic Old Age Security System

Source: data from 1999 to 2003 come from China Labor Statistical Yearbook (2000-2004); data in 2004 comes from annual statistical communiqué of the Ministry of Labor and Social Security.

As the reforms moved ahead, the coverage of urban old age security system has been gradually expanded. From 1989 to 2003, the number of urban workers participating in the basic old age insurance scheme across China increased from 48.17 million to 122.5 million, with a rising participation rate from $33.5 \%$ to $46.3 \%$. Of those participating in the basic old age insurance scheme, the number of urban retirees increased from 8.93 million to 40.13 million, 4.6 times that of 1989 (See Figure 1).

Urban elders enjoy a high coverage of old age security. According to the 2000 Census, labor participation rate of urban population aged 60 and above is 13 percent. Of urban 
non-working urban elders, 56.2 percent receive pension benefits, 38.8 percent depend on family support, and 5 percent rely on other means of support. However, according to the 2000 China Urban and Rural Elderly Survey, 70.7 percent of urban elders aged 60 and above receive pension benefits and 12.1 percent live on social old age insurance, the combination of these two groups totaling 82.8 percent.

The social security status for urban elders improved thanks to the increases in subsidies outlay from government financial transfer and the lifting of pooling level for basic old age insurance funds. The retiree benefits rose to 9047 Yuan in 2003, 7734 Yuan higher than 1990, 5.3 times that of 1990. Delivering pensions by social service institutions ensures timely issuance at full amount. In the past, enterprises were responsible for the delivery of pensions to their employees. In 1998, the share of pension delivery by social service institutions was only 30 percent. By 2003, it amounted to 35.58 million persons, 99.5 percent of the total pensioners, and 60.5 percent higher than that in 1998.

\section{Rural Old Age Security System Reform}

Prior to reforms, rural old age security took a model of low-level collective system. Under rural people's communes, land and other basic means of production were collectively owned. Farmers were organized to work together and a unified distribution was implemented. The Household Registration System prohibited the free migration of farmers to prevent the shocks on urban welfare system. Rural laborers are entitled to distribution of products through participating in the production and operation of rural economic collectives. Only when they totally lose the ability to work are they eligible to withdraw from production activities and taken care of by family members. Childless and disable old persons are guaranteed food, clothing, medical care, housing and burial expenses by the collectives.

The introduction of Household Responsibility System dismantled the institutional basis for collective-based social security system in rural areas. The basic guarantees previously provided by the collectives, including employment, income and old age security, are now farmers' own responsibilities. Although the state calls for the establishment of a double-track management system that combines unified and separate operations, collective economy no longer exists in the 
vast majority of rural areas. Rural communities lack organizational resources to effectively provide income security and medical care to rural residents.

China began to try out reforming old age security system in some of the rural areas and urban areas almost simultaneously. In 1986, pilot projects for establishing an old-age social insurance system were carried out in rural areas, starting from economically developed areas. After a period of experiments, the Ministry of Civil Affairs in 1992 promulgated Basic Program for Rural Social Security Insurance at County Level, calling for a rural social old age insurance system with county as the basic operation unit. Adhering to the principle of establishing a rural old age insurance system mainly funded by individual contributions with supplemental collective-sponsored contributions and governmental policy support, China has set up individual pension accounts managed by county governments, and encouraged one-child parents to participate in this program by the provision of higher subsidy standard from the collectives.

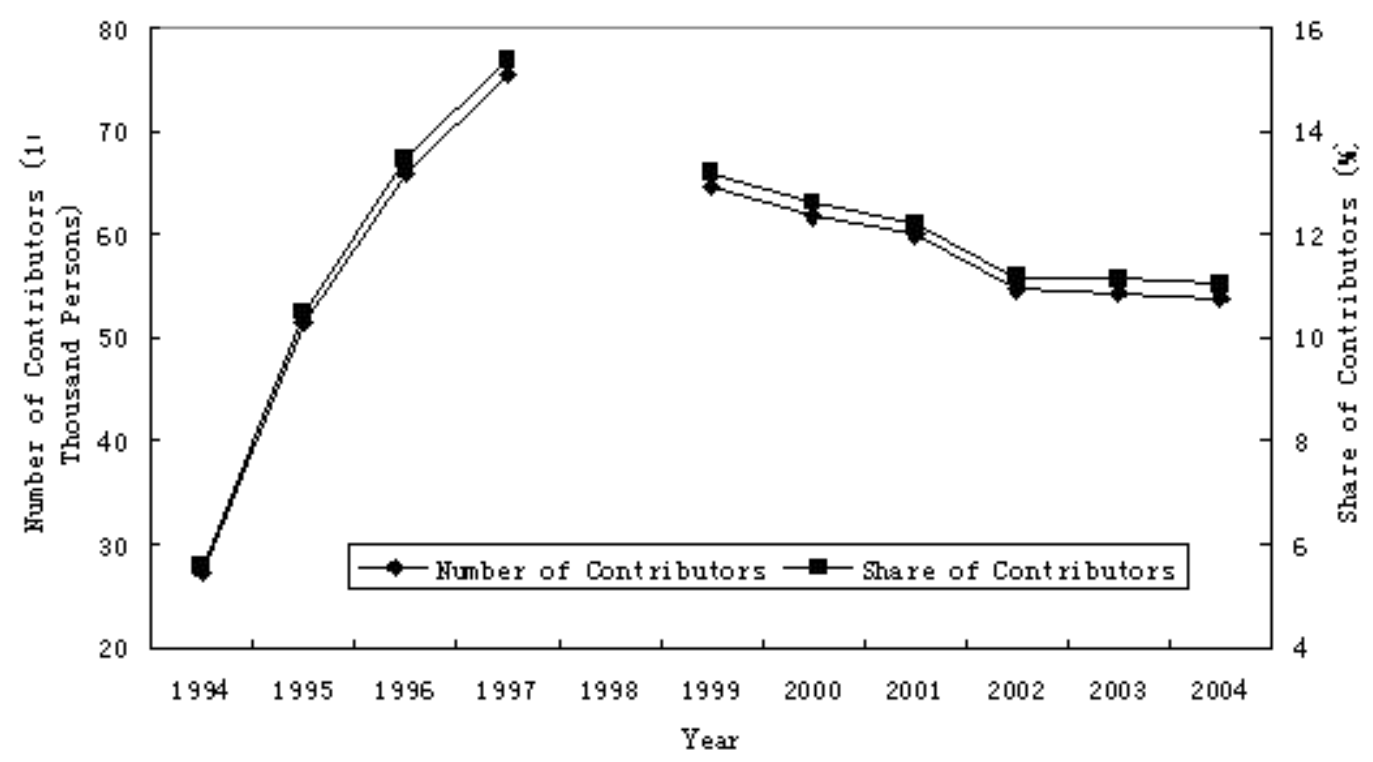

Figure 2. Coverage of Rural Social Pension Insurance

Note: data in 1998 is not available

Source: data from 1994 to 1997 come from annual statistical communiqués of the Ministry of Civil Affaires; data from 1999 to 2003 come from China Labor Statistical Yearbook (2000-2004); data in 2004 come from annual statistical communiqué of the Ministry of Labor and Social Security.

These measures stimulated farmers' willingness to participate in the old age insurance 
program. By the end of 1997, 75.42 million farmers had underwritten the insurance scheme. But after 1998, the development of rural old age security system ground to a halt. The government restructuring in 1998 transferred the work of rural old age security from the Ministry of Civil Affairs to the Ministry of Labor and Social Security. In July 1999, the State Council pointed out that the conditions were absent in rural areas to carry out old age security on a large scale, decided to rectify the existing businesses, stop accepting new businesses and encouraged the regions with appropriate socio-economic conditions to gradually move toward commercial insurance. During this period, the majority of rural areas saw a decline in the number of farmers with insurance and increasing difficulties in the operation of old age insurance funds due to institutional and policy changes. In 2004, 53.78 million farmers underwrote the insurance scheme, 21.64 million less than 1997, a 28.7 percent drop. The percentage of farmers insured in the total rural labor forces fell from 15.4 percent in 1997 to 11.0 percent in 2004 (See Figure 2).

At present, rural elders mainly depend on family support. According to the 2000 Census, labor participation rate of rural population aged 60 and above is 43.4 percent. Of non-working rural elders, 8.2 percent have pension benefits, 86.2 percent depend on family support, and 5.7 percent rely on other means. However, according to the 2000 China Urban and Rural Elderly Survey, 5.4 percent of the rural elders aged 60 and above have pension benefits and 1.5 percent live on social old age insurance, the combination of these two groups only totaling 6.9 percent, while 85.0 percent rely on family support.

\section{The Vulnerability of Urban Old Age Security System}

Nominally, urban pension system implements a combination of scaled-back pay-as-you-go benefits and partially individual contributory pension accounts. Under the 1997 reform, urban employees are divided into three groups with different basic old age insurance benefits. The "old men”, those who were already retired in 1997, will continue to receive pre-reform benefits that typically replace 80 percent of wages. The "new men”, those who join after 1997, will receive a pay-as-you-go benefit and a personal account benefit. The "middle men", those who were contributing workers in 1997, will receive partial benefits under both systems. The reform intended to finance the retirement of the participants in the pre-reform system through pooling of 
social basic pension funds.

However, the new system inherited huge deficits from preexisting liabilities of the old system. The Ministry of Labor and Social Security acknowledged that the current deficit of 2500 billion Yuan would balloon into some 6000 billon Yuan in 30 years, according to an article in Legal Daily on May 8, 2005. This number is perhaps still an underestimate. The World Bank estimated a deficit of 3000 - 4000 billion Yuan. If the transition cost is to be spread out in 50 years, assuming a deficit of 3700 billion Yuan and an average interest rate of 4 percent, each year has a transition cost of 160 billion Yuan; with an average interest rate of 5 percent, each year will have a transition cost of 190 billion Yuan (Sun, 2001).

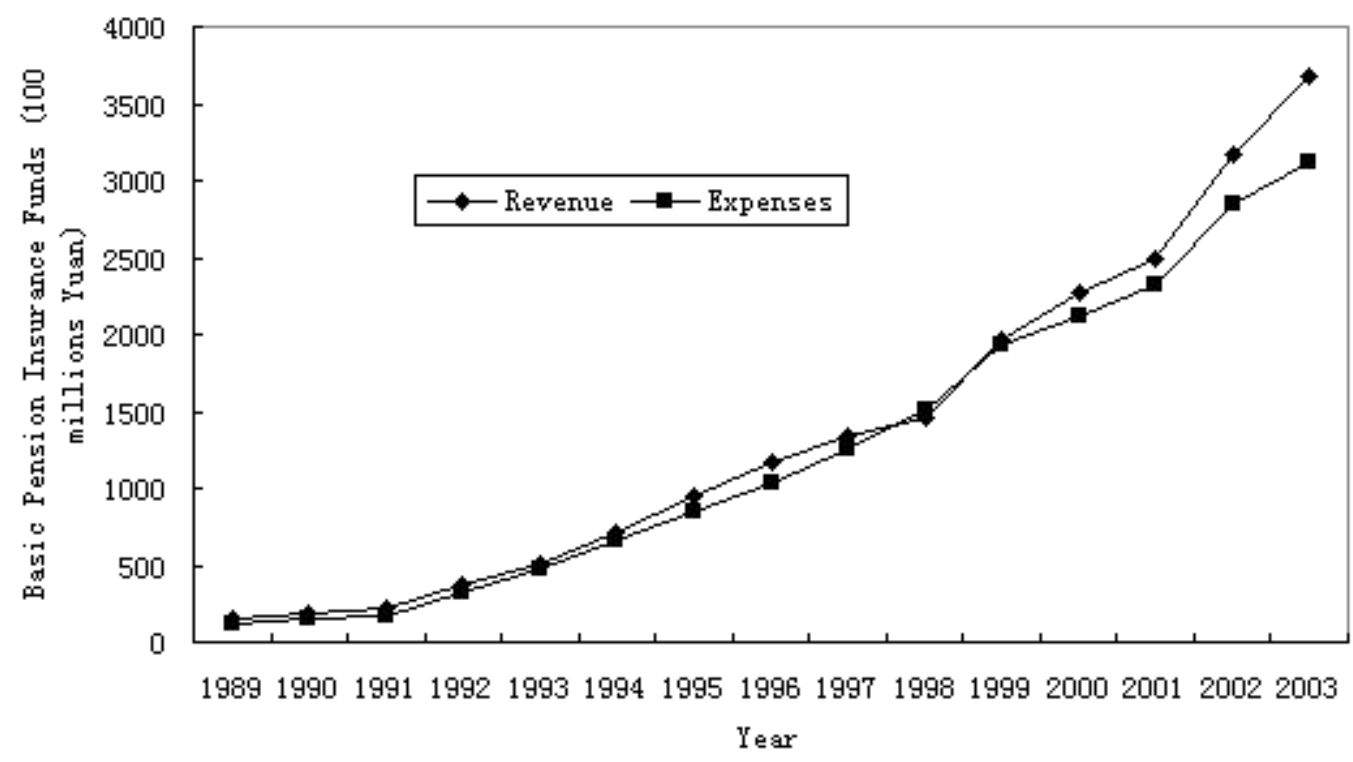

Figure 3 Trends of Revenue and Expenses of Urban Basic Pension Insurance Funds

Source: National Statistic Bureau, China Labor Statistical Yearbook (2000-2004), China Statistics Press, Beijing.

In reality, pay-as-you-go system is still used to deliver urban old age pension security (See Figure 3). Since contributions to both tiers of the pension system are deposited in the same government bank accounts, local governments routinely "borrow" individual account contributions to cover cash shortfall in social pools. Therefore, the empty accounts problem was produced at birth of the new system and is getting worse over time. The 14 billion Yuan worth of empty accounts in 1997 increased to 200 billion Yuan in $2000 . \quad$ In order to prevent social problems that might be prompted by pension arrears, the state has to fill the deficit with 
subsidies. In 2001, the central government transferred 98.2 billion Yuan to fill in the gap, 5 times that of 1998.

The defects in institutional design are to blame for enterprises' unwillingness to join the basic social pool. The absence of an incentive mechanism coupled with partial-funding-partial-payment system makes social pooling a direct payment transfer between enterprises. New enterprises with less retiree routinely underpay or even refuse to pay contributions. Old enterprises, overburdened with a contribution rate as high as 30 percent, regard evasion an income source. Contribution evasion is equivalent to a certain profit returns, therefore, most of enterprises tried to take measures such as hiring temporary and short-term contract workers, reducing total payroll and number of actual employment to escape the contributory responsibility (Zhang and Qiu, 2003). In the meantime, 80 percent of participants in the basic social pool are State-Owned Enterprise (SOE) workers. As most of SOEs are unprofitable and cannot afford insurance premium, social security bureaus have to raise contribution rate to make up for the dwindling insurance fund, which results in a vicious circle.

Empty accounts and low expected returns also cause the failure to attract more participants to join the basic old age insurance. In the multiple pillars recommended by the World Bank, the mandatory individual pension account is individually-owned. But in China, the ownership of individual account is in legal limbo. The mixed management of social pools and individual accounts lends itself to the problem of diverting individual account contributions to cover deficits in the social pools. Individual accounts have become purely "notional". The government lowers the returns on individual accounts in order to cut its liabilities to future pension benefits. When the return on individual accounts is lower than the opportunity cost, contribution evasion is inevitable (Zhao and $\mathrm{Xu}, 2000$ ). In this scenario, it's almost impossible to ensure the genuine funding of individual accounts, which further exacerbates the collection and accumulation of individual accounts.

China's immature capital market offers few options to the investment of social security fund and the returns are low. In early days, the government strictly regulated that 80 percent of social security funds should be invested in government bonds and 20 percent should be deposited in bank accounts (West, 1997; Feldstein, 1998). On the balance sheet of 2004 social security funds, bank deposits and long-term bonds accounted for 53.9 percent and trust investment accounted for 
35.8 percent. The average returns of social security fund were lower than 3 percent from 2001 to 2003 and 3.3 percent in 2004, all of which lower than the 6 percent actual returns of long-term social security fund internationally.

Although urban basic old age insurance has enlarged its coverage range since 1999, it failed to raise the coverage ratio in urban workers. In 2004, only 46.3 percent of urban workers participated in the basic old age insurance, about the same as that in 1995 . However, the ongoing demographic change has increased the burden of urban old age security system. In 1990, there were 6.1 workers for every retiree. In 2003, this number fell to 2.7. Even taking into consideration the inflow of young rural migrants, the rising pressure on the urban social security system is hardly mitigated.

In light of international experiences, a sustained pay-as-you-go pension system needs three prerequisites (Cai and Meng, 2004): (1) a relatively young demographic structure to provide for the existing pensioners; (2) an effective taxation system to levy potential premiums for old age insurance; (3) an efficient and safe mechanism to manage and administer pension funds, ensuring the value and appreciation of the funds through proper investments. With none of the three prerequisites, China cannot operate the pay-as-you-go pension system to provide a sustainable old age security net to urban elderly.

\section{The Importance of Rural Old Age Security System}

A sustained rural family-based old age security system calls for the following prerequisites: (1) a relatively large household population size to share incomes or avoid risks; (2) a source of stable income to maintain the living standard; (3) a good social network (such as relatives, neighbors and friends) to minimize external risks that are difficult to borne by a single family.

With the socio-economic transformation, rural family-based old age security faces unprecedented challenges. Firstly, the implementation of family planning policy in rural areas downsizes families, shifting them from extended families to nuclear families. The average population per household fell from 5.7 in 1978 to 4.1 in 2003, and will decline in the long run. Secondly, rural-to-urban population migration leads to an older rural population. According to the 2000 Census, the elderly made up 7.5 percent of rural population as compared to 6.4 percent of 
urban population. Under the constraints of Household Registration System, few farmers migrate the whole family to urban areas. The majority of migrants to urban areas are young working adults. On top of that, as western "individualistic" value gain currency, more and more elders find it difficult to live with children. Speeding up urbanization will contribute to the further aging of rural population. Thirdly, the security and incomes coming from farmland have been declining. Despite the dual roles farmland plays in rural household business, i.e., means of production and livelihood, farmland cannot become the major income source and safety net for farmers, due to its small scale, lack of liquidity and unstable ownership. Farmers are increasingly relying on non-agricultural sectors as their major income sources. Fourthly, the function of rural social network has been on the decline. The ratio of income transfer between rural households to rural per capita net income fell from 11.7 percent in 1980 to 3.7 percent in 2003. In addition, the collective economy in rural area has been in decline, rendering it unable to provide any relief to households in difficulty.

With the downward trend of family-based rural old age security, it is necessary to establish a formal old age security system in rural areas to ensure old age support in the midst of dramatic socio-economic transformation. The stagnation and even recession in the development of rural old age security system since 1998 were not only the results of mismanagement and low coverage rate of rural old age insurance system, but also the government's unwillingness to make financial commitment to set up such a system. One of the official considerations is that China's low level of economic development renders it immature to establish an old age security system in rural areas. This judgment is wrong.

In terms of historic experience in some European countries, Denmark, Sweden, Portugal and Spain began legislation for the establishment of rural old age security system in 1891, 1913, 1919 and 1947, respectively. Per capita GDP of these four countries at those times were equivalent to 79.3 percent, 99.9 percent, 46.6 percent and 73.3 percent of China's per capita GDP in 1999 at a comparable basis (Zeng, 2005). Most of the 15 EU membership countries didn’t have basic old age security for farmers at the very beginning and integrated farmers into their social security system from late to the end of $20^{\text {th }}$ century. In terms of agricultural labor share, agricultural output, per capita income level, China's development level and rural economic level have been on par with or exceeded the corresponding average conditions of those countries at those times (Yang 
it. al., 2004). Therefore, economic development level shouldn't be a constraint and it is now the time to establish a rural old age security system in China.

From a strategic perspective, the establishment and improvement of an old age security system in rural areas will have important implications. Firstly, setting up a rural old age security system is important to cope with rural aging population. At present, two-third of China's elderly live in rural areas. After the establishment of urban old age security system, the government should shift emphasis to rural areas. Any delay in preparing for the age wave will miss the current opportunities. Moreover, the underdeveloped rural old age security system will increase the pressure on "Five Guarantees" system and minimum living allowance system. The key is to choose a good model for rural old age security. If rural old age security adopts individual pension accounts as its funding strategy, the government will not have to make full financial commitment and therefore will not be overburdened.

Secondly, the establishment of an old age security system in rural areas is crucial to the balanced development and integration of rural and urban economies. Since 1990s, rural-urban income gap has widened and this trend will not stop in a foreseeable future. In the long term, to narrow rural-urban disparity makes it necessary to reduce the number of farmers and the ratio of agricultural employment and at the same time improve agricultural productivity. This means that a great amount of rural labor forces need to migrate and choose to permanently settle down in cities. The integration of rural and urban labor markets is a prerequisite for smoothing the movement of rural to urban migration, and old age security system is a supportive basis of effective operation of labor markets. Obstacles in the course of urbanization include issues of providing old age security for rural labors and landless farmers, and integrating rural social security system with urban social security system. If China fails to solve these problems, migration will bring rural poverty into urban areas and exacerbate the poverty problem in cities, which challenges the healthy development of urbanization.

Finally, the establishment of an old age security system in rural area will activate the function of production factors of farmland, optimize the gender ratio of rural population and promote rural development. The establishment of old age security in rural areas will partially replace the security function of farmland, contribute to the transformation of farmland's function as a production factors, and accelerate the liquidity of farmland and the enlargement of production 
scale. In addition, old age security will reduce rural families' reliance on children in old age, thus reducing male preference fertility and improving the gender ratio in rural areas.

China could learn from Japan’s experience in regulating labor migration and land liquidity through pension policy (Yang, it. al., 2004). Since 1970, Japan began to establish old age insurance in rural areas. By 2002, Japanese farmers' national annuity had three components: basic pension, old age annuity and land right transfer compensation. After 2002, Japanese farmers' old age insurance consisted of two components: national annuity (basic pension, equivalent payment excluding land right transfer compensation) and agricultural workers’ annuity (plan DC). The Basic Law on Agricultural Workers'Annuity in 1970 stipulated that farmers must transfer the full management right of land upon withdrawing from agricultural production and will get a one-time subsidy, which is indexed with commodity prices. This policy not only increased benefits to rural elders but also encouraged farmers to migrate to urban areas and enlarge production scale. With the aging of rural population, Japan adopted a new agricultural annuity system in 2002, which intended to encourage young farmers to stay in rural areas by terminating the compensation for transfer of land management right.

\section{Elderly Poverty and Old Age Security}

In his pioneering work on poverty, Rowntree (1901) divided life into five key periods: childhood, early working adulthood, parenthood, working life after children have grown up, and old age. Three periods in the life cycle (including childhood, parenthood and old age) have the highest exposure to poverty-stricken risks. When people become old and withdraw from labor market, the savings and pension contributions accumulated in the working time period will directly determine their livelihood status in old age. If individuals, families and society have made necessary preparation for the old age, the probability that the elderly fall into poverty will be largely reduced. Otherwise they will face a high risk.

Using the 2000 China Urban and Rural Elderly Survey, Wang and Zhang (2005) made estimation on elderly poverty at the national level: the aggregate quantity of elderly poverty population is 9.21-11.68 million with a poverty incidence of 7.1-9.0 percent, of which urban elderly poverty population is $1.85-2.46$ million with a poverty incidence of $4.2-5.5$ percent, 
and rural elderly poverty population is 7.36-9.22 million with a poverty incidence of 8.6-10.8 percent.

A general profile for elders who are in poverty or not are as follows: urban elders, who are male, aged 75 and under, with higher education attainment, good health, good marital status, assured security and non-agricultural household registration, are less likely to be impoverished. On the contrary, female elders aged 75 and above, with low education attainment, bad health, living alone, without assured security and having agricultural household registration, are more likely to slide into poverty. Analysis of rural elderly population shows similar results but little difference between genders.

Controlling other variables, the econometric analysis revealed the following results: (1) women are less likely to be impoverished than men; (2) age variable doesn’t have significant impact on elderly poverty; (3) individual characteristic variables, such as education attainment and political party membership, have significant positive impacts on elderly poverty; (4) participating in labor market has certain impact on urban elderly poverty alleviation whereas little impact on rural elderly poverty; (5) social security, family support and self-insurance have dramatic impacts on elderly poverty. Obviously, gender and age are not the factors on their own that have direct impacts on elderly poverty, while the socioeconomic factors attached to gender and age such as education, security status, difference in income generation at working status, preparation for old age, and so on have direct impacts on elderly poverty.

If individuals, families and society haven't prepared for the aged, the dynamics of elderly poverty will pose enormous challenges to its alleviation. Once elders withdraw from labor market, they cease income generation and lose earnings sources. If there are no other sources of income, elderly poverty will be prone to be a chronic poverty when individual savings run out. Moreover, the ongoing demographic change will lead to more and more senior elderly people, whose higher disease incidence will definitely drive an increasing demand for medical expenditures and health cares. However, the deficiency of medical care and income security cannot meet the gap between individual needs and expenditures, and will in turn prompt higher poverty incidence in the senior elderly people. Therefore, it is important to set up an old age security system to provide support for old age and alleviate elderly poverty. 


\section{Building up A Sustained Old Age Security System}

With the decline of working age population, within 20 or 30 years after 2020, China's social burden for old-age security will grow to an unbearable extent. China’s elderly population aged 65 and above will exceed 100 million in 2005,about 7.5 percent of total population, and will leap to more than 10 percent by 2020. China will enter a more severely aging society in 2040 with an elder aged 65 and above in every five persons (See Figure 4). Considering the current and future economic development level in decades, the aging challenge arising from increasing demands for old age security is rather tremendous. Therefore, it is urgent for China to reform and adjust urban and rural old age security system geared towards the demographic change, and eliminate its vulnerability to be better prepared for the aging society.

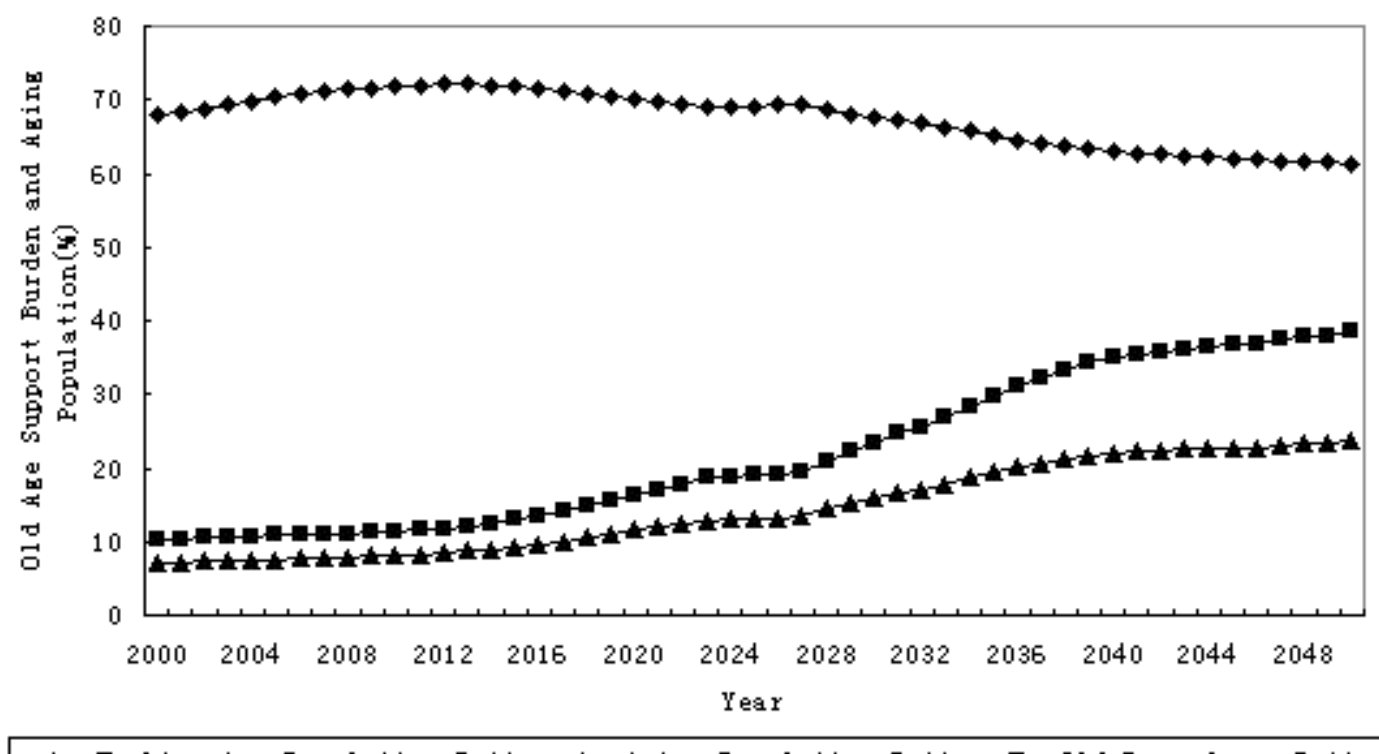

*- Morking Age Population Ratio - Aging Podulation Ratio -

Figure 4. China's Old Age Support Burden and Population Aging Trend

Note: population estimate is made assuming 1.8 as total bearing rate

Source: the estimated figures are from by Wang Guangzhou, China research center for population and development.

Building up a new fully individual contributory system is a way out for China's old age security system. Compared with the current pay-as-you-go system, this fully individual 
contributory fund raising and delivering system can encourage individual savings for old age through setting up mandatory individual account, preserve and appreciate the value of pension funds by means of individual risk-taking capital market, and improve the management and governance of pension funds under the market mechanism. This institutional arrangement not only reduces the transition cost of urban old age security system to the maximum extent, but also accelerates the construction of rural old age security system by appropriate policy measures, and finally constructs a sustained old age security system consistent with China's situation to provide for the old.

As for the urban old age security system, the introduction of a new model should set up individual accounts for "new men" and "transitional men” with a fully individual contributory system, which will absorb "transitional men" by accumulation of pension funds from pay-as-you-go system in 2035 and have a full coverage for urban workers by the new system afterwards. It will reduce the old dependency ratio from 44 percent in the old pay-as-you-go system to 32 percent in 2020. If rural migrants are allowed to participate in the new system, the old dependency ratio will further reduce to 25.3 percent in 2020. Therefore, the opening of urban old age security system to rural migrants could enhance the funding capability of “transitional men” and reach the goal of a smooth institutional transition (Cai and Meng, 2004).

The rural old age security system, outlined in Rural Basic Old Age Insurance Program, which consists mostly of voluntary beneficiary-financed individual pension accounts, supplemented with collective-sponsored pensions, will give farmers a real incentive to join the system without overburdening the government. Past experiences have born testimony to this. Through pooling various financial resources of indirect agricultural subsidy, direct income subsidy and poverty alleviation funds, China has the conditions to further develop the rural old age security system with a combination of individual account pensions, family support (farmland security) and state minimum living allowance, extending an old age security net to every rural elder. In light of Japanese experiences, China can deposit the compensation for farmland use right transfer to farmers' individual accounts, which will greatly reduce the burden on the government to provide for minimum living allowance and promote the liquidity of farmland. The reform will steer China away from traditional form of family-based old age security toward family-plus-social old age security, and ultimately purely social old age security. 
The establishment of a fully individual contributory account system will provide a platform for integrating urban and rural old age security systems. In other words, the urban model of social-pool-plus-individual-accounts system and the rural model of farmland-security-plus-individual-accounts system operate independently and in parallel. With the development and improvement of these two models, the individual accounts of rural migrants and landless farmers could be portable through sound design and management, and incorporated into the urban old age security system, and thus pave a path for the smooth integration of rural migrants into urban society.

\section{Reference}

Cai, Fang, and Meng Xin, 2004. Demographic change, institutional transition and the sustainability of pension system in China, Comparison, No.1.

Sun, Qixiang, 2001. Empty account and transition cost: the effects of China's pension system reform, Journal of Economic Research, No.5.

Wang, Dewen, and Zhang Kaiti, 2005. What and how the elderly lives under poverty in China, Journal of Chinese Population Science, No.1.

Yang, Yansui, Zhao Jianguo, and Han Junping, 2004. Strategic implications of the construction of rural pension system, Strategy and Management, No.2.

Zhang, Liguan, and Qiu Changrong, 2003. Causes of contribution evasion of old age social insurance and its countermeasure in China, Finance and Trade Economy, No.9.

Zhao Yaohui, and Xu Jianguo, 2000. Issues of urban pension system transition, Reform, No.3.

Zeng, Yi, 2005. Pension gap and rural basic old age social security, http://www.cpirc.org.cn/news/rkxw gn detail.asp?id=5452.

Feldstein, Martin, 1998. Social security pension reform in China, NBER Working Paper 6794, Cambridge, MA 02138.

Rowntree, B.S., 1901. Poverty: A Study of Town Life, Macmillan.

West, A. Loraine, 1997. Pension reform in China: preparing for the future, Eurasia Bulletin, Summer 1997, pages 9-19.

National Statistical Bureau, China Labor Statistical Yearbook (2000-2004), China Statistics Press, Beijing. 